\title{
NOVAS ANOTAÇÕES SOBRE AS EMPRESAS ESTATAIS
}

\section{VÍTOR RHEIN SCHIRATO*}

I. Introdução; II. Formas e Conceitos das Empresas Estatais; III. Classificação das Empresas Estatais; 111.1. Empresas Estatais Prestadoras de Serviços Públicos; III.1.1. Empresas Estatais e Concessão de Serviços Públicos; III. 2. Empresas Estatais Exploradoras de Atividades Econômicas; 1II.2.1. Casos de Exploração de Atividades Econômicas Previstos na Constituição Federal; III. 2.1.1. Monopólios; III. 2.2. Imperativos de Segurança Nacional e Relevante Interesse Coletivo; III.3. Empresas Estatais que Exercem Funções Públicas; IV. Regime Juridico Aplicável às Empresas Estatais; IV.1. Empresas Estatais que Exercem Funções Públicas; IV.2. Empresas Estatais Prestadoras de Serviços Públicos; IV.2.1. Serviços Públicos e Atividades Econômicas Reguladas; IV.3. Empresas Estatais Exploradoras de Atividade Econômicas; V. Natureza dos Bens das Empresas Estatais; VI. Empresas Estatais e Regulação Econômica; VII. Conclusão

\section{Introdução}

Ao longo das últimas duas décadas, vem sendo verificada no Brasil (bem como em grande parte dos países ocidentais) uma significativa alteração das funções e das finalidades das empresas estatais existentes, bem como daquelas que foram desde então constituídas. Tal alteração consta, em linhas gerais, de modificações da postura do Estado com relação ao desempenho de atividades econômicas e à prestação de serviços públicos.

Como consequiência de tais modificações, foram implementados, tanto em âmbito federal (Lei ${ }^{\circ} 9.491$, de 9 de setembro de 1997), quanto em âmbito estadual (de acordo com a legislação de diversos estados), programas de privatização, que culminaram com a transferência para a iniciativa privada do controle de diversas

* Advogado em São Paulo. Mestrando em Direito pela Universidade de Osnabrück, Alemanha. 
empresas estatais exploradoras de atividades econômicas e prestadoras de serviços públicos'.

Adicionalmente aos processos de privatização, outra relevante alteração no papel das empresas estatais vem sendo verificada ultimamente. Tal alteração concerne à constante e crescente utilização da forma societária para a constituição de entidades exercentes de funções públicas, anteriormente exercidas exclusivamente por órgãos da Administração direta ou por autarquias.

Desta forma. vê-se por um lado significativa redução do papel das empresas estatais nos campos da exploração de atividades econômicas e da prestação de serviços públicos (atividades econômicas em sentido amplo) e. por outro lado, um número significativo de empresas estatais constituídas para o exercício de funções públicas.

À luz de tal alteração fática no campo de atuação das empresas públicas e sociedades de economia mista, teremos por objetivo neste estudo analisar, sob os auspícios da Constituição Federal e da legislação aplicável, as novas funções das empresas estatais, bem como o regime jurídico a elas aplicável de acordo com as atividades por elas desempenhadas.

\section{Formas e Conceitos das Empresas Estatais}

O termo Empresas Estatais inclui no direito brasileiro três espécies de entidades, quais sejam, as empresas públicas, as sociedades de economia mista, bem como aquelas demais sociedades existentes e controladas pela iniciativa privada que vieram a ser adquiridas pelo Pode Público sem autorização legislativa específica ou sem observar os procedimentos aplicáveis às empresas públicas ou sociedades de economia mista.

No direito brasileiro, a conceituação legal de empresas públicas e sociedades de economia mista provém do Decreto-Lei $\mathrm{n}^{\circ} 200$, de 25 de fevereiro de 1967 (conforme alterado pelo Decreto-Lei $\mathrm{n}^{\circ} 900$, de 29 de setembro de 1969). Todavia, é absolutamente unânime na doutrina de direito administrativo nacional que os conceitos contidos em referido diploma legal são equivocados e não refletem a real

I Valendo-nos de conceito presente na doutrina alemã, pode-se dizer que os programas de privatização conduzidos no Brasil incluíram tanto privatizaçōes funcionais. quanto privatizações materiais. Segundo Thomas Volimöller, privatização funcional é aquela que representa a transferência à iniciativa privada apenas da execução (Vollzug) de determinada atividade. permanecendo a responsabilidade (Aufgabenverantwortung) por sua execução com a Administração Pública. De outra forma. privatização material é aquela que representa a transferência à iniciativa privada tanto da execução da atividade. quanto da responsabilidade por sua execução. Em analogia aos programas de privatização promovidos no Brasil, podemos, portanto. dizer que as empresas estatais prestadoras de serviços públicos privatizadas fizzeram parte de privatizações funcionais, enquanto as empresas estatais exploradoras de atividades econômicas em sentido estrito privatizadas ri reram parte de privatizações materiais. Cf. VOLLMÖLLER, Thomas. Die Wirtschaftliche Be'ititgung der öffentlichen Hand. In SCHMIDT, Reiner/VOLLMÖLLER, Thomas (Org.). Kompendium Öffentliches Wirtschaftrecht. $2^{a}$ edição -2004 . Ed. Springer. Heidelberg. Página 143. 
função das empresas públicas e sociedades de economia mista, visto determinarem que tais entidades serão constituídas exclusivamente com a finalidade de explorar atividades econômicas sem que seja feita qualquer referência à possibilidade de prestação de serviços públicos (atividades econômicas em sentido amplo) portais entidades?

Tendo em vista não haver grandes debates doutrinários relacionados ao conceito de empresas públicas e sociedades de economia mista, para os fins deste estudo, propomos a seguinte conceituação para definir empresas públicas e sociedades de economia mista:

Empresas Públicas são entidades constituídas pelo Estado, sob quaisquer das formas admitidas em direito privado. mediante a edição de lei autorizadora, para o exercido de atividade econômica (em sentido estrito), para a prestação de serviço público ou para a realização de funções públicas, com personalidade jurídica de direito privado e capital subscrito e integralizado com recursos oriundos exclusivamente do Poder Público.

Sociedades de economia mista são sociedades anônimas, cuja criação é autorizada por lei, nas quais há o encontro de capitais públicos com capitais privados para a prestação de um serviço público ou para a exploração de uma atividade econômica (em sentido estrito), com personalidade jurídica de direito privado, sendo o Poder Público, necessariamente, o acionista controlador'.

Diante dos conceitos apresentados acima, é importante mencionar que a constituição de uma empresa pública ou de uma sociedade de economia mista dependerá, obrigatoriamente, da edição de lei ordinária autorizadora. Tal obrigação decorre do inciso XIX do artigo 37 da Constituição Federal, que dispõe (in verbis). "somente por lei específica poderá ser criada autarquia e autorizada a instituição de empresa pública. sociedade de economia mista e de fundação, cabendo à lei complementar, neste último caso, definir suas áreas de atuação".

Ademais, cabe ressaltar que a lei autorizadora não efetivamente constituirá uma empresa estatal, mas sim apenas autorizará sua constituição, uma vez que a efetiva

2 Os incisos II e III do Decreto Lei 200/67 conceituam, respectivamente, empresa pública e sociedade de economia mista federais como (in verbis): "a entidade dotada de personalidade jurídica de Direito Privado, com patrimônio próprio e capital exclusivo da União, criada por lei para a exploração de atividade econômica que o Governo seja levado a exercer por força de contingência ou conveniência administrativa podendo revestir-se de quaisquer das formas admitidas em direito" e "a entidade dotada de personalidade jurídica de Direito Privado, criada por lei para a exploração de atividade econômica, sob a forma de sociedade anônima, cujas ações com direito a voto pertençam èm sua maioria à União ou a entidade da Administração indireta". 3 Para os fins do conceito ora trazido à baila, o termo acionista controlador deverá ser interpretado de acordo com a definição constante do artigo 116, da Lei 6.404, de 15 de dezembro de 1976. que dispõe (in verbis): “Art. 116. Entende-se por acionista controlador a pessoa. natural ou jurídica, ou o grupo de pessoas vinculadas por acordo de voto. ou sob controle comum que: a) é titular de direitos de sócio que lhe assegurem, de modo permanente, a maioria dos votos nas deliberações da assembléia geral e o poder de eleger a maioria dos administradores da companhia: e b) usa efetivamente seu poder para dirigir as atividades sociais e orientar funcionamento dos órgãos da companhia." 
constituição de uma empresa pública ou de uma sociedade de economia mista dependerá do cumprimento de todas as formalidades previstas na legislação do Direito Empresarial, conforme a forma societária adotada (no caso das empresas públicas).

Em âmbito federal. as empresas públicas poderão revestir-se de qualquer das formas admitidas em direito, bem como de formas novas, que venham a ser criadas especialmente para a constituição de determinada empresa pública federal (como ocorre, por exemplo, com a Caixa Econômica Federal, constituída na forma de sociedade unipessoal). Distinta é a condição das empresas públicas estaduais e municipais. que somente poderão revestir-se das formas empresariais atualmente existentes em direito, sendo-lhes vedada a adoção de novas formas especialmente criadas. Tal vedação é devida à competência privativa da União para legislar sobre direito comercial prevista no inciso I do artigo 22 da Constituição Federal ${ }^{4}$.

Exatamente por conta desta vedação, os Estados e Municípios em diversas oportunidades constituem empresas na forma de sociedades anônimas que passam a ser consideradas sociedades de economia mista, quando, na realidade, são empresas públicas. Tal errônea consideração advém da existência de ações detidas por pessoas alheias à Administração Pública. Todavia, é de se ressaltar que, por força da legislação societária, em nenhuma hipótese a totalidade das ações de uma sociedade anônima será detida pela Administração Pública, uma vez que os membros do Conselho de Administração de uma sociedade anônima serão, obrigatoriamente, acionistas de tal companhia, nos termos do artigo 146 da Lei 6.404/76.

Assim sendo, entendemos que as sociedades anônimas constituídas exclusivamente com recursos públicos, nas quais apenas as ações detidas pelos membros do conselho de administração não são detidas pela Administração, configuram-se empresas públicas e não sociedades de economia mista. Esta afirmação é ratificada, ainda, pelo fato de que a integralização dos valores referentes às ações detidas pelos membros do Conselho de Administração são desembolsados pela própria Administração, que transfere tais ações aos membros do Conselho de Administração condicional e exclusivamente pelo período em que desempenham a função de administradores e após o qual são obrigados a restituir ao Poder Públicos as ações por eles detidas.

Por fim. deve-se mencionar que, inobstante serem as empresas estatais entidades constituídas pelo Poder Público para realizar funções de interesse coletivo (seja no campo da exploração de atividade econômica em sentido estrito, seja no campo da prestação de serviços públicos), essas têm natureza jurídica de pessoas de direito privado, uma vez que são constituídas como pessoas jurídicas de direito privado. Todavia, o regime jurídico de direito privado das empresas estatais será, obrigatoriamente, híbrido, com forte influência do regime jurídico de direito público. Esta influência do regime de direito público será menos ou mais intensa conforme a atividade desempenhada pela empresa estatal em questão, conforme será descrito posteriormente.

4 Cf. DI PIETRO, Maria Sylvia Zanella. Direito Administrativo. $14^{\mathrm{a}}$ edição - 2002. Ed. Atlas. São Paulo. Página 389. 


\section{Classificação das Empresas Estatais}

Afirmamos acima que as empresas estatais poderão ser as empresas públicas, sociedades de economia mista, bem como as demais empresas privadas controladas pelo Poder Público, adquiridas sem autorização legislativa. Todavia, ao mencionarmos a classificação as empresas estatais, procederemos a uma distinção das empresas estatais conforme as atividades por elas desempenhadas, sendo tal classificação fundamental para a determinação do regime jurídico aplicável a referidas empresas.

\section{III.l. Empresas Estatais Prestadoras de Serviços Püblicos}

A maior parte das empresas estatais foi constituída, ou adquirida, pelo Poder Público, com a finalidade de prestar serviços públicos. Segundo Celso Antônio Bandeira de Mello, "serviço público é toda atividade de oferecimento de utilidade ou comodidade material fruivel diretamente pelos administrados, prestado pelo Estado ou por quem lhe faça as vezes, sob regime de Direito Público - portanto, consagrador de supremacias e de restrições especiais —, instituído pelo Estado em favor de interesses que houver definido como próprios no sistema normativo" 5 .

De acordo com o artigo 175 da Constituição Federal, a prestação dos serviços públicos incumbe ao Poder Público, que deverá prestá-los diretamente ou mediante a outorga de concessão ou permissão ${ }^{6}$. A prestação dos serviços públicos incumbirá à União, aos Estados e Distrito Federal ou aos Municípios de acordo com as divisões de competências previstas na Constituição Federal, em seus artigos 21 e seguintes.

Desta forma, pode-se entender que o Poder Público, para o desempenho de atividades que the são constitucionalmente designadas (i.e., serviços públicos), poderá tanto optar por desempenhá-las diretamente, quanto criar entidade em sua administração indireta sob seu controle para desempenhá-las, quanto, ainda, proceder à outorga de concessão ou permissão para que terceiros venham a desempenhar tais atividades.

\section{III.1.1. Empresas Estatais e Concessão de Serviços Públicos}

Comumente, há aqueles que sustentam que a constituição de empresa estatal para a prestação de serviços públicos implica na existência de concessão de um serviço público ${ }^{7}$. Entendemos ser tal assertiva falsa, pois a constituição de empresa

5 MELLo. Celso Antônio Bandeira de. Curso de Direito Administrativo. $13^{a}$ edição - 2001. Ed. Malheiros. São Paulo. Página 597.

6 Dispõe o artigo 175 da Constituição Federal (in verbis). "Art. 175. Incumbe ao Poder Público, na forma da lei, diretamente ou sob regime de concessão ou permissão, sempre através de licitação, a prestação de serviços públicos. Parágrafo único. A lei disporá sobre: I - o regime das empresas concessionárias e permissionárias de serviços públicos, o caráter especial de seu contrato e de sua prorrogação, bem como as condições de caducidade, fiscalização e rescisão da concessão ou permissão: II - os direitos dos usuários; III - politica tarifária; IV - a obrigação de manter serviço adequado."

7 Segundo Marcai Justen Filho, concessão de serviço é "um contrato plurilateral, por meio do 
estatal para a prestação de um serviço público nada mais é do que uma discricionariedade $^{8}$ da qual o Poder Público dispõe para a organização do desempenho das atividades que the são próprias, a ser adotada exclusivamente com base em razões de conveniência e oportunidade. E manifestação do poder de auto-organização da Administração'.

Assim, diante das disposições constitucionais aplicáveis (notadamente o artigo 175), entende-se que o Poder Público, além da possibilidade de outorga de concessões ou permissões, poderá, na prestação direta dos serviços públicos, tanto prestá-los de forma centralizada, por meio de órgão da administração direta, quanto de forma descentralizada, por meio de empresa estatal ou outra entidade da administração indireta, conforme expressamente previsto em lei ${ }^{10}$.

A necessidade de lei advém da submissão da Administração Pública ao Princípio da Legalidade que determina que somente a lei poderá estabelecer competências administrativas ${ }^{\prime \prime}$ (artigo 37, caput, da Constituição Federal), bem como da necessi-

qual a prestação de um serviço público é temporariamente delegada pelo Estado a um sujeito privado que assume seu desempenho diretamente em face dos usuários, mas sob controle estatal e da sociedade civil, mediante remuneração extraida do empreendimento, ainda que custeada

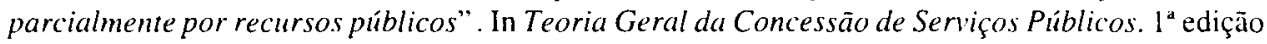
- 2003. Ed. Dialética. São Paulo. Página 96.

8 Celso Antônio Bandeira de Mello brilhantemente define discricionariedade administrativa como: " a margem de liberdade que romanesca ao administrador para eleger, segundo critérios consistentes de razoabilidade, um. dentre pelo menos dois comportamentos cabiveis, perante cada caso concreto. afim de cumprir o dever de adotar a solução mais adequada à satisfação da finalidade legal, quando. por força de fluidez das expressões da lei ou da liberdade conferida no mandamento. dela não se possa extrair objetivamente, uma soluçāo unívoca para a situação vertente." In Discricionariedade e Controle Jurisdicional. $2^{a}$ edição - $5^{\mathrm{a}}$ tiragem - 2001. Ed. Malheiros. São Paulo. Página 48. No caso em apreço, a discricionariedade advém da possibilidade de livre escolha conferida pela Constituição à Administração para prestação diretamente (de forma centralizada ou descentralizada) dos serviços públicos, ou mediante concessão ou permissāo.

9 Hannut Maurer define o poder de organização da Administração Pública (Organisationsgewait) como: "o poder de estabelecimento, alteração e revogação de sujeitos administrativos (entidades. autarquias e fundações de direito público) e de órgãos administrativos (...)." In Algemeines Verwaitungsrecht. $14^{\mathrm{a}}$ edição - 2002. Ed. C. H. Beck. Munique. Página 543.

10 Neste sentido, afirma Celso Antônio Bandeira de Mello: "O Estado tanto pode desenvolver por si mesmo as atividades administrativas que tem constitucionalmente a seu encargo. como pode prestá-las através de outros sujeitos. Nesta segunda hipótese, ou transfere a particulares o exercicio de certas atividades que lhe são próprias ou, entāo, cria outras pessoas, como entidades adrede concebidas para desempenhar cometimentos de sua alçada. Ao criá-las, a algumas conferirá personalidade de Direito Público e a outras personalidade de Direito Privado. Por meio delas, então, descentralizará as sobreditas atividades. Pelo contrário, quando as desempenha ele próprio. Estado, estará mantendo tais atividades centralizadas." In MELLO, Celso Antônio Bandeira de. Curso op. cit. Página 105.

11 Celso Antônio Bandeira de Mello define competências administrativas como: "círculo compreensivo de um plexo de deveres públicos a serem satisfeitos mediante o exercício de correlatas e demarcados poderes instrumentais, legalmente conferidos para satisfação de interesses públicos." In Curso. op. cit., Página 110. 
dade de autorização legislativa para a constituição de empresa estatal mediante (artigo 37, inciso XIX, da Constituição Federal).

Desta forma, entendemos que a constituição de empresa estatal para o desempenho de serviço público não implica a existência de concessão de serviço público, mas sim deflagra apenas processo de descentralização administrativa, levado a cabo dentro do poder de auto-organização da Administração Pública, respeitados os requisitos constitucionalmente estabelecidos (autorização legislativa).

Ao comentar a situação jurídica das empresas estatais prestadoras de serviços públicos, Eros Grau, com extrema precisão, afirma que "são situações jurídicas inteiramente distintas pois, a do concessionário de serviço público e a da empresa estatal que tenha por objeto a sua prestaçāo. Estas, ao contrário do que estive anteriormente a sustentar, são delegadas do Estado, criadas no bojo do movimento da descentralização administrativa, para fim específico. Ė o próprio Estado, então, quem através de uma sua extensão, dotada de personalidade jurídica privada, presta os serviços". ${ }^{2}$

Distinta, todavia, é a situação das empresas estatais prestadoras de serviços públicos controladas por um ente federativo que não é o competente para a prestação dos serviços prestados. Conforme mencionado acima, a Constituição Federal reparte entre os entes da federação distintas competências para a prestação de serviços públicos.

Por exemplo, a União Federal é competente para prestar os serviços públicos de energia elétrica e de exploração dos portos marítimos, fluviais e lacustres, entre outros serviços (Constituição Federal, artigo 21, inciso XII, alíneas " $b$ " e " $f$ ", respectivamente). Assim, caso haja uma empresa estatal controlada por um Estado ou um Município que venha a prestar qualquer de referidos serviços, haverá. inegavelmente, concessão de serviços públicos. Isto ocorre, pois não há o que se falar em descentralização administrativa entre entes distintos da federação. A relação entre a União Federal e as empresas estatais em hipóteses deste jaez passará a ser típica de uma concessão de serviços públicos ${ }^{13}$.

A corroborar este entendimento, é possível mencionar o $\S 1^{\circ}$ do artigo $17 \mathrm{da}$ Lei 8.987 , de 13 de fevereiro de $1995^{14}$, que determina que nas licitações para a outorga de concessões de serviços públicos serão desclassificadas as propostas apresentadas por empresas estatais controladas por ente federativo alheio à esfera político-administrativa do poder concedente que necessitem de vantagens ou subsídios de seu controlador para sua viabilização. A partir de tal dispositivo, não só é possível concluir pela existência de relação jurídico-administrativa de concessão de

12 GRAU, Eros Roberto. A Ordem Econômica na Constituição de 1988. $7^{\text {a }}$ edição - 2002. Ed. Malheiros. São Paulo. Página 171.

13 Cf. MELLO, Celso Antônio Bandeira de. In Curso, op. cit. Página 160.

14 Dispõe o $\$ 1^{\circ}$ do artigo 17 da Lei $8.987 / 95$ (in verbis): "Considerar-se-á, também, desclassificada a proposta de entidade estatal alheia à esfera político-administrativa do poder concedente que. para sua viabilização, necessite de vantagens ou subsidias do poder político controlador de referida entidade." 
serviço público nas hipóteses de serviços prestados por empresa estatal controlada por ente federativo que não é o competente para a prestação de tais serviços, como podemos, inclusive, afirmar que estas concessionárias estarão em condições de estrita igualdade com as empresas privadas que venham a ser concessionárias de serviços públicos. ressalvada, obviamente, a aplicabilidade das disposições constitucionais e legais pertinentes (notadamente, artigo 37 da Constituição Federal e Lei 8.666, de 21 de fevereiro de 1993$)^{15}$.

\section{III.2. Empresas Estatais Exploradoras de Atividades Econômicas}

Além das empresas estatais prestadoras de serviços públicos (atividades econômicas em sentido amplo), há também aquelas empresas estatais constituídas com a finalidade de explorar atividades econômicas em sentido estrito, constitucionalmente reservada à iniciativa privada (Constituição Federal, artigos 173 e 174).

Tarefa extremamente árdua, todavia, resta em definir um conceito de atividade econômica; sobretudo ao se ter em vista que os serviços públicos são atividades econômicas, porém titularizadas pelo Estado em razão da intrínseca relação com interesse público que possuem. No caso em análise, porém, não há dúvidas de que o conceito de atividade econômica utilizado para a classificação desta segunda forma de empresa estatal refere-se às atividades econômicas em sentido estrito, excluindose, portanto, os serviços públicos.

$\mathrm{Na}$ análise desta questão, Marcai Justen Filho afirma que "A atividade econômica em sentido restrito peculiariza-se pela exploração econômica lucrativa, segundo principios norteadores da atividade empresarial, fundada na racionalidade estritamente econômica. $O$ conceito pressupõe a utilização especulativa da propriedade privada, visando precipuamente à realização do interesse dos particulares. Tal conceito delineia-se, portanto, sobre os princípios da exploração empresarial. da livre iniciativa e da livre concorrência. Pressupõe que os sujeitos possam organizar os fatores da produção para a obtenção de resultados não predeterminados pelo Estado, com a apropriação privada do lucro" ${ }^{16}$.

A partir da brilhante colocação acima apresentada, partiremos do pressuposto de que atividades econômicas em sentido estrito são todas as atividades que tenham como resultado a movimentação de riqueza, excepcionados os serviços públicos, realizadas preferencialmente pela iniciativa privada em regime de livre iniciativa e livre concorrência ${ }^{17}$ de acordo exclusivamente com os critérios considerados ade-

15 A aplicabilidade dos dispositivos ora mencionados implica na obrigatoriedade das empresas públicas e sociedades de economia mista concessionárias de serviços públicos de realizar concursos públicos para a admissão de seus funcionários, licitações anteriormente a suas contratações, entre outros aspectos.

16 JUSTEN FILHO, Marçal. O Direito das Agências Reguladoras Independentes. $1^{\mathrm{a}}$ edição 2002. Ed. Dialética. São Paulo. Página 310.

17 A este respeito, afirma Marcai Justen Filho: "A atividade econômica é reservada preferencialmente aos particulares, que a desempenham como derivação do princípio da propriedade privada. 
quados pelos particulares para a satisfação de seus interesses, sob um regime de direito privado.

Nos termos do artigo 173 da Constituição Federal, a exploração de atividades econômicas em sentido estrito, que, como vimos, é reservada aos particulares, somente poderá ser realizada pelo Estado (i) nos casos previstos na Constituição Federal, (ii) quando necessária aos imperativos da segurança nacional, ou (iii) quando necessária para atender ao interesse público, sendo que nestes últimos dois casos, conforme previsto em lei. A Administração Pública, contrariamente do que se verifica com relação à iniciativa privada, não se aplica o Princípio da Livre Iniciativa, consagrado no caput do artigo 170 da Constituição Federal como fundamento da Ordem Econômica constitucional ${ }^{18}$.

\section{III.2.1. Casos de Exploração de Atividades Econômicas Previstos na Constituição Federal}

Quanto à primeira hipótese, casos previstos na Constituição Federal, há (ou houve) apenas dois casos de atividades econômicas em sentido estrito, quais sejam, os casos de monopólio (atualmente, apenas concernentes à exploração de atividades da indústria nuclear, nos termos do inciso XXIII do artigo 21 e inciso V do artigo 177 da Constituição Federal) e os casos das instituições financeiras públicas, previstas no inciso I do artigo 192 da Constituição Federal, anteriormente à revogação promovida pela Emenda Constitucional $n^{\circ} 40$, de 29 de maio de $2003^{19}$.

Segundo a precisa conceituação apresentada pelo Ministro Eros Roberto Grau, na exploração de atividades econômicas em regime de livre concorrência, o Estado realiza intervenção no domínio econômico por participação, visto que participa da economia juntamente com as pessoas privadas, ao passo que na exploração de monopólios, o Estado realiza intervenção no domínio econômico por absorção, visto que elide a participação das pessoas privadas, absorvendo-as ${ }^{20}$.

\section{III.2.1.1. Monopólios}

O monopólio sobre as atividades previstas nos incisos I a IV do artigo 177 da Constituição Federal teve seu caráter severamente atenuado quando da edição da Emenda Constitucional $\mathrm{n}^{\circ} 9$, de 9 de novembro de 1995, que passou a permitir à

Aplicam-se os princípios da livre iniciativa e da livre concorrência." In O Direito, op. cit. Página 312.

18 Cf. VOLLMÖLLER, Thomas. Gewerbrecht. In SCHMIDT, Reiner/VOLLMÖLLER, Thomas (org.). Kompendium, op. cit. Página 244.

19 Anteriormente à promulgação de referida emenda constitucional, dispunha o inciso I do artigo 192 da Constituição Federal (in verbis). "I - a autorização para o funcionamento das instituições financeiras, assegurado às instituições bancárias oficiais e privadas acesso a todos os instrumentos do mercado financeiro bancário, sendo vedada a estas instituiçōes a participação em atividades não previstas na autorização de que trata este inciso" (grifos nossos)

20 GRAU, Eros Roberto. Ordem, op. cit. Página 175. 
União outorgar concessões e autorizações para empresas públicas ou privadas desenvolverem as atividades lá arroladas, quais sejam, (i) a pesquisa e a lavra das jazidas de petróleo e gás natural e outros hidrocarbonetos fluidos, (ii) refinação do petróleo nacional ou estrangeiro, (iii) importação e exportação dos produtos ou derivados básicos resultantes das atividades descritas em (i) e (ii). e (iv) o transporte marítimo do petróleo bruto de origem nacional ou de derivados básicos de petróleo produzidos no País, bem como o transporte dutoviário de petróleo bruto. seus derivados e gás natural de qualquer origem.

$\mathrm{Na}$ esteira da alteração constitucional efetivada por meio da Emenda 9/95, foi editada a Lei 9.478 , de 6 de agosto de 1997, nos termos da qual foi regulamentada a outorga de concessões e autorizações para o desenvolvimento de referidas atividades. Em linhas gerais, as atividades de pesquisa e lavra das jazidas de petróleo e gás natural dependem de concessão da União Federal, nos termos dos artigos 21 e seguintes da Lei 9.478/97. enquanto as demais atividades descritas dependem de simples autorização a ser outorgada pela Agência Nacional do Petróleo, ente regulador dos mercados de gás e petróleo, criado por meio da Lei 9.478/97.

Desta forma, após a promulgação da Emenda Constitucional 9/95 e a edição da Lei $9.478 / 97$, as atividades dantes alçadas constitucionalmente a monopólio da União Federal passaram a ser atividades econômicas reguladas, nas quais os particulares poderão ingressar mediante a anuência da União Federal, observados os requisitos necessários (licitação prévia nos casos em que seja necessária a outorga de concessão).

Da mesma forma, a Petróleo Brasileiro S.A. - Petrobras, anteriormente exploradora das atividades da indústria do petróleo em regime de monopólio passou a atuar em regime de livre competição com a iniciativa privada, bem como passou à condição de concessionária da União Federal para explorar e produzir petróleo no Brasil, conforme expressamente previsto nos artigos 31 e seguintes e 61 e seguintes da Lei 9.478/97, que ainda, expressamente revogou a Lei 2.004, de 3 de outubro de 1953, que disciplinava a exploração, pela União Federal, do monopólio sobre as atividades da indústria do petróleo e o exercício das atividades da Petrobras.

Ademais, cabe ressaltar a questão dos serviços postais. Nos termos da Lei $n^{\circ}$ 6.538, de 22 de junho de 1978, os serviços postais constituem-se monopólio da União Federal, explorado pela Empresa de Correios e Telégrafos. Todavia, muito se questiona acerca (i) da recepção, pela Constituição Federal de 1988, de tal monopólio, e (ii) da existência ou não de monopólio em referida atividade visto serem os serviços de correios e telégrafos serviços públicos (atividades econômicas em sentido amplo). Desta forma, passaremos, neste ponto, a fazer uma brevíssima análise desta questão.

Quanto ao primeiro questionamento, i.e., recepção pela Constituição de 1988 do monopólio previsto na Lei 6.538/78, entendemos não ter havido recepção de referido dispositivo e, portanto, inexistir monopólio sobre as atividades de serviços postais, inobstante reiteradas decisões judiciais em sentido contrário ${ }^{21}$. O posiciona-

21 Entre outras decisões. Recurso Extraordinário $n^{\circ} 220.906-9 / D F$ e Recurso Extraordinário $n^{\circ}$ $220.041-5 /$ RS. 
mento ora exposto é baseado na previsão expressa no texto constitucional de todas as atividades consideradas monopolizadas pela União Federal, sem que haja qualquer possibilidade de previsão de monopólios em lei ordinária, tal como ocorria anteriormente 22 .

Nos regimes constitucionais anteriores, havia expressamente a possibilidade da União, por meio de lei ordinária, transformar determinada atividade em monopólio estatal, desde que atendidos os requisitos previstos nas Cartas Políticas anteriores. Ao lume de tal permissão, foram disciplinados por lei ordinária diversos dos monopólios estatais, tais como o monopólio sobre as atividades da indústria do petróleo (Lei 2.003/54, revogada pela Lei 9.478/97), o monopólio sobre as atividades da indústria nuclear (Leis $n^{\circ} 4.118$, de 27 de agosto de 1962 e $n^{\circ} 5.740$, de $1^{\circ}$ de dezembro de 1971) e o monopólio sobre os serviços postais (Lei 6.538/78), Quanto aos dois primeiros monopólios aqui referidos (indústrias do petróleo e de bens nucleares), há expressa previsão no texto constitucional acerca da manutenção da existência de tais monopólios (artigo 177 da Constituição Federal, sem prejuízo da flexibilização do monopólio sobre as atividades da indústria do petróleo acima descrita). Porém, tal não é a situação dos serviços postais, que não têm expressa referência constitucional como atividades constituintes de monopólio nacional.

Ora, se o legislador constituinte previu expressamente quais atividades permaneceriam sob monopólio estatal e dentre tais atividades deixou de incluir os serviços postais e, ainda, passou a vedar a monopolização de atividades por meio de lei ordinária, não há como entendermos que os serviços postais, cujo monopólio não tem referência constitucional, mas apenas em lei ordinária, permanecem no rol das atividades econômicas monopolizadas pela União Federal.

Esse entendimento é compartilhado por José Afonso da Silva, que afirma: " $A$ Constituição não é favorável aos monopólios. (...). O monopólio público também ficou bastante limitado, pois já não se declara, como antes, a possibilidade de monopolizar determinada indústria ou atividade. Declara-se a possibilidade de exploração direta de atividade econômica quando necessária aos imperativos de segurança nacional ou relevante interesse coletivo (art. 173). Parece-nos que aí não entra o monopólio, que é reservado só para as hipóteses estritamente indicadas no art. 177 (...)." 23

Quanto à segunda questão suscitada, entendemos que os serviços postais são serviços públicos e não atividades econômicas, o que afasta completamente a possibilidade da existência de monopólio sobre os serviços postais, visto que somente as atividades econômicas em sentido estrito poderão ser monopolizadas e somente diante de expressa disposição constitucional. Como já visto, os serviços públicos, por força do artigo 175 da Constituição Federal, são de incumbência do Poder Público que, poderá, quando julgar necessário, outorgar concessões ou permissões para que terceiros os prestem.

22 Por exemplo, o $\$ 8^{\circ}$ do artigo 157 da Constituição de 1967 e o artigo 146 da Constituição de 1946 autorizavam a constituição de monopólios mediante a edição de lei ordinária federal.

23 SILVA, José Afonso da. Curso de Direito Constitucional Positivo. 22a edição - 2003. Ed. Malheiros. São Paulo. Página 761. 
No caso específico dos serviços postais, $o$ inciso $X$ do artigo 21 da Constituição Federal $^{24}$ faz expressa referência aos serviços postais como serviços, mesma redação utilizada para designar outras atividades inequivocamente incluídas no rol dos serviços públicos (tais como, energia elétrica na alínea "b" do inciso XII do artigo 21 e telecomunicações no inciso XI do mesmo artigo 21). Ademais, os serviços postais podem ser perfeitamente incluídos na definição de serviços públicos acima exposta (item III[a]).

Por fim, é de se ressaltar que os serviços postais são serviços públicos para os quais não existe a possibilidade de outorga de concessões ou permissões, devendo. portanto, ser prestados de forma direta pela União Federal. Tal fato decorre da própria redação do inciso $\mathrm{X}$ do artigo 21 da Constituição Federal, que, ao contrário de outros serviços públicos constitucionalmente arrolados em tal artigo, não prevê a possibilidade de prestação mediante concessão ou permissão.

Sendo assim, a Empresa de Correios e Telégrafos - ECT não é empresa estatal exploradora de atividade econômica monopolizada pela União Federal, mas sim entidade da administração indireta federal prestadora, por meio de processo de descentralização administrativa, de serviços públicos de competência da União Federal, sendo-lhe, portanto, aplicável o regime aqui descrito às empresas estatais prestadoras de serviços públicos.

As únicas empresas estatais exploradoras de monopólios federais que remanescem em nosso sistema jurídico, portanto, são a Indústrias Nucleares do Brasil INB, sociedade de economia mista controlada pelo Ministério de Ciência e Tecnologia à qual incumbe explorar as atividades da indústria nuclear, e a Termonuclear S.A., subsidiária da Centrais Elétricas do Brasil S. A. - Eletrobrás, à qual incumbe a exploração das usinas de geração de energia elétrica nuclear Angra I e Angra II.

\section{III.2.2. Imperativos de Segurança Nacional e Relevante Interesse Coletivo}

Vistos os casos de exploração de atividades econômicas expressamente previstos na Constituição Federal, passaremos neste momento a brevemente analisar as demais hipóteses de exploração de atividades econômicas pelo Poder Público. Conforme mencionado previsto no artigo 173 da Constituição Federal, o Poder Público somente poderá explorar atividades econômicas nos casos necessários aos imperativos da segurança nacional ou ao relevante interesse coletivo. conforme previsto em lei.

José Afonso da Silva afirma que estas hipóteses de exploração de atividades econômicas pelo Estado são aquelas consideradas necessárias, visto que, ocorridos os requisitos previstos na Constituição Federal (imperativos de segurança nacional e relevante interesse coletivo), deverá o Poder Público explorar determinada atividade econômica ${ }^{25}$.

24 Dispõe o inciso $X$ do artigo 21 da Constituição Federal (in verbis): "Art. 21. Compete à União:

(...) X-manter o serviço postal e o correio aéreo nacional." (Grifos Nossos)

25 Cf. SILVA, José Afonso da. Curso op. cit. Página 780. 
Assim, quanto às hipóteses de exploração de atividade econômica em comento, devemos mencionar que (i) somente poderão ocorrer diante da verificação dos requisitos constitucionais pertinentes, cessados os quais deverá o Poder Público imediatamente suspender a exploração da atividade econômica, e (ii) dar-se-ão em regime de livre concorrência com a iniciativa privada.

Por fim, resta-nos, ainda, analisar uma última questão concernente à possibilidade de outros entes federativos, além da União, explorarem atividades econômicas com fundamento no artigo 173 da Constituição Federal. Segundo nosso entendimento, não há qualquer óbice para que Estados, Distrito Federal e Municípios explorem atividades econômicas nos casos em que necessário para atendimento ao relevante interesse coletivo, uma vez que o interesse coletivo poderá ter traço regional, típico de ser atendido pelo ente federativo competente.

Todavia, o mesmo não ocorre com os casos de exploração de atividades econômicas quando necessário aos imperativos da segurança nacional, uma vez que somente a União Federal será competente para definir quais os imperativos da segurança nacional e quais as medidas necessárias para o atendimento a tais imperativos (competências privativas da União previstas nos incisos I a IV do artigo 21 da Constituição Federal, por exemplo).

Sendo assim, diante do exposto neste item, podemos concluir que as empresas estatais exploradoras de atividades econômicas são (i) aquelas constituídas pela União para explorar atividades constitucionalmente consagradas como monopólios federais, (ii) aquelas instituições financeiras constituídas por qualquer dos entes federativos até a edição da Emenda Constitucional $n^{\circ} 40 / 2003$, (iii) aquelas constituídas por qualquer dos entes federativos para a exploração de atividades necessárias à satisfação do interesse coletivo relevante (que poderá ter caráter exclusivamente regional), e (iv) aquelas constituídas pela União para explorar atividades necessárias aos imperativos de segurança nacional.

\section{III.3 Empresas Estatais que Exercem Funções Públicas}

Conforme mencionamos na introdução deste estudo, há certo tempo vem tornando-se mais comum a adoção da forma societária para a constituição de instituições cujos objetivos resumem-se ao exercício de funções públicas (ou serviços públicos atividades administrativas). Tais funções podem ser consideradas serviços públicos, contudo em acepção bastante ampla e diferenciada daquela até este momento utilizada neste trabalho.

Até aqui, serviços públicos foram tratados como atividades econômicas em sentido amplo, ou seja, como uma forma de atividade econômica titularizada pelo Estado em razão de sua relevância para o atendimento do interesse público. Todavia, referimo-nos neste ponto a outra atividade precípua da Administração Pública, porém que não pode ser considerada atividade econômica, tal como os serviços públicos até este momento analisados.

Por esta razão, há aqueles que, abalizados pelas lições da doutrina italiana, preferem referir-se a tais atividades como "Funções Públicas" e não como serviços públicos por entenderem que as funções públicas não podem ser incluídas na mesma 
categoria dos serviços públicos ${ }^{26}$. Para os fins deste estudo adotaremos sem qualquer ressalva as nomenclaturas "Serviços Públicos Atividades Administrativas" ou "Funções Públicas".

Vista esta questão terminológica, passaremos a examinar o conceito destas funções públicas (ou serviços públicos atividades administrativas). Adotaremos aqui o conceito de que funções públicas são todas as atividades precípuas do Estado, na qualidade de entidade soberana. Vale dizer, funções públicas são todas aquelas atividades exercidas pelo Estado relacionadas à sua organização, às suas funções políticas e ao exercício de sua autoridade e, consequientemente, ao seu poder de unilateralmente constituir os particulares em obrigações, constante do denominado poder de polícia, ou Administração Ordenadora, segundo a precisa nomenclatura adotada por Carlos Ari Sundfeld ${ }^{27}$.

Posto isto, devemos analisar a possibilidade de se adotar a forma societária, com personalidade jurídica de direito privado, para exercer funções públicas, notadamente as atividades da Administração Ordenadora, tal como vem sendo feito cada vez com maior freqüência no Brasil.

No conceito de empresas estatais apresentado por Thomas Vollmöller, essas somente poderão ser constituídas para explorar atividades que tenhan uma finalidade econômica, sendo inaceitável para o autor a adoção da forma societária para o exercício de funções sociais ou administrativas ${ }^{28}$. Lição semelhante é amplamente aceita no Brasil por diversos doutrinadores.

Para o exercício das funções da Administração Ordenadora, aceitam pacificamente a doutrina e jurisprudência nacionais a existência de órgão da Administração direta ou a criação, por lei, de uma autarquia.

Segundo valiosa lição de Celso Antônio Bandeira de Mello, “ autarquias podem ser conceituadas como "pessoas jurídicas de Direito Público de capacidade exclusivamente administrativa." "29. Segundo o mestre, "a razão de ser da autarquia é o prosseguimento de fins estatais, ou seja, a realização de interesses públicos a ela confiados, pelo que, ao geri-los. satisfaz, contemporaneamente, finalidade sua e do Estado, pois ambas se igualam" 30 .

26 Cf. JUSTEN FILHO. Marçal. Teoria, op. cit. Páginas 22 e 23. Na mesma linha. Augustín Gordillo afirma que os serviços públicos são atividades monopolísticas exercidas pelo Estado ou por um particular a partir de um privilégio outorgado pelo Estado. Em contrapartida. Poder de Polícia seria " uma faculdade ou atribuição do Estado, que entre outras coisas se supõe que limita e controla esse poder monopolistico outorgado pelo Estado." In Tratado de Derecho Administra-

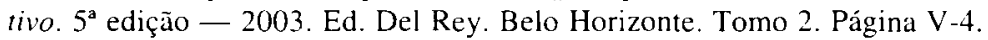

27 Carlos Ari Sundfeld há muito vem substituindo o termo Poder de Polícia por Administração Ordenadora, a qual. consoante entendimento do ilustre professor "consiste na interferência estatal autoritária sobre a vida privada. Supõe o emprego de instrumentos com intensidades e finalidades muito variadas, incidindo sobre a esfera jurídica dos particulares em múltiplas variações." In Direito Administrativo Ordenador, $1^{a}$ edição. $3^{a}$ tiragem - 2003. Ed. Malheiros. São Paulo. Página 26.

28 Cf. VOLL.MÖLlER, Thomas. Die Wirtschafrliche, op. cit. Página 140.

29 MELLO, Celso Antônio Bandeira de. Curso, op. cit. Página 123.

30 MELLO, Celso Antônio Bandeira de. Natureza e Regime Jurídico das Autarquias. $1^{\mathbf{a}}$ edição 1968. Ed. Revista dos Tribunais. São Paulo. Página 230. 
Muita resistência ainda permanece na doutrina e na jurisprudência brasileiras à utilização de empresas estatais para o exercício de funções da Administração Ordenadora. Contudo, a nosso ver, respeitados certos limitadores que serão adiante expostos, não vemos qualquer óbice à utilização de empresas estatais para o exercício de determinadas funções públicas, sendo este, possivelmente, o ponto mais controvertido deste estudo. Vale dizer, não nos opomos à idéia de que empresas estatais realizem interesses públicos a elas confiados.

Como mencionado, é pacífica a aceitação da delegação a autarquias do exercício das funções da Administração Ordenadora. De acordo com a conceituação de autarquia normalmente aceita (incluindo aquela exposta acima), podemos compreender que as autarquias são pessoas jurídicas de direito público, com patrimônio, receitas e personalidade jurídica próprios, criadas pelo Estado, por meio de lei, para a persecução de determinada finalidade pública, possuindo capacidade administrativa específica e sendo controladas pelo órgão da Administração direta que as houver criado, sem que haja subordinação. Ao final do dia, as autarquias nada mais são do que um patrimônio organizado para o exercício de uma função exclusivamente administrativa de acordo com um regime jurídico exclusivamente de direito público.

Como qualquer forma de entidade devidamente constituída de acordo com as regras de direito (sejam regras de direito público, ou de direito privado) para um determinado fim, deverá haver um patrimônio destinado a possibilitar o exercício da atividade almejada, bem como deverá haver a designação de dirigentes da entidade a ser criada, a fim de que haja quem possa conduzir a entidade ao cumprimento de suas atividades, administrar o patrimônio afetado e responder perante a entidade constituinte e a sociedade de uma forma geral pelos atos praticados.

No caso específico das autarquias, os recursos necessários para amealhar o patrimônio afetado são advindos do Poder Público e os dirigentes designados são nomeados diretamente pelo Chefe do Poder Executivo (em âmbito federal, artigo 84, inciso II, da Constituição Federal) e, salvo disposição legal em sentido contrário, destituíveis ad nutum igualmente pelo Chefe do Poder Executivo. Conforme mencionado acima, as autarquias sujeitam-se ao controle do Ministério (em âmbito federal) ou da Secretaria (em âmbitos estadual e municipal), não havendo subordinação.

Em breve exercício de abstração, passemos a analisar a estrutura de uma empresa pública de acordo com as regras aplicáveis (normas de direito privado que regerão sua constituição). Para a constituição de uma empresa pública, é necessária a destinação de recursos que serão afetados ao exercício de suas atividades, o que é chamado em direito privado de capital social. Da mesma forma, independentemente da forma societária adotada pela empresa pública a ser constituída, deverão ser designados seus administradores, elegíveis e destituíveis a qualquer tempo pelo órgão societário competente (em última análise, o acionista ou quotista controlador da empresa em questão), que serão responsáveis pela aplicação e gestão dos recursos e pelos atos praticados pela empresa.

Postas estas afirmações, vejamos. Os recursos a serem destinados à formação do capital social da empresa pública serão advindos exclusivamente do Poder Público e os administradores de referida instituição serão nomeados pelo órgão societário 
competente (novamente, o acionista ou quotista controlador da empresa pública), que será representado, necessariamente, pelo Poder Público, na pessoa do Chefe do Poder Executivo, e serão por ele a qualquer tempo destituíveis. Há, igualmente, o controle do Ministério ou da Secretaria à qual a empresa estatal em análise se vincula (artigo 70 da Constituição Federal e artigos 13 e 19 do Decreto-Lei 200/67).

Ora, estamos diante uma situação na qual há duas formas de organização de entidades, uma de direito público (autarquia) e outra de direito privado (empresa pública), nas quais os recursos necessários à constituição de ambas as entidades e ao exercício de suas atividades advêm exclusivamente do Poder Público. Da mesma forma, os dirigentes de ambas as entidades são nomeados e destituíveis a qualquer tempo pelo Chefe do Poder Executivo.

Sendo assim, qual a diferença prática existente entre uma autarquia e uma empresa pública? Como já exaustivamente afirmado, a única diferença consiste no fato de uma ter personalidade de direito público (autarquia) e a outra personalidade de direito privado (empresa pública). Todavia, tal diferença é por si só bastante para ipso facto rejeitarmos a possibilidade de uma empresa estatal exercer atividades da Administração Ordenadora, como inquestionavelmente aceitamos para as autarquias? Entendemos que não e passaremos neste ponto a expor as razões de nosso entendimento.

Preliminarmente, deparamo-nos con a questão do regime aplicável aos servidores (termo este que aqui é usado em sentido amplo, que a seguir será especificado) das empresas públicas e das autarquias. Há tempos é consensual o entendimento de que nas autarquias haverá sempre cargos públicos, com a vigência de regime estatutário $^{31}$, assegurando-se ao ocupante do cargo todas as prerrogativas inerentes a tal regime, ao passo que nas empresas estatais haverá sempre empregos públicos, com a vigência do regime celetista e todos os direitos a ele inerentes.

A luz da distinção essencial concernente ao regime adotado para as relações lavorais dos servidores das autarquias (termo aqui empregado com sentido específico para designar os servidores públicos em regime estatutário) e os empregados das empresas estatais, muitos doutrinadores entendem não ser possível o exercício de atividades da Administração Ordenadora pelas empresas estatais. por faltar a seus empregados a estabilidade e a independência necessárias ao desempenho de suas funções.

Permissa máxima vênia das posições em sentido contrário, não compartilhamos do mesmo entendimento, pois, com o advento da Constituição Federal de 1988, os regimes de cargo e emprego público foram consideravelmente aproximados. Tal aproximação, em primeiro lugar, decorre da necessidade de concurso público para a investidura, tanto nos cargos públicos, quanto nos empregos públicos, consoante previsão expressa do inciso II do artigo 37 da Constituição Federal ${ }^{32}$. Em segundo

31 Em âmbito federal, inclusive. a Lei 8.112. de 11 de dezembro de 1990. expressamente determina que o único regime aplicável aos servidores das autarquias federais será o estatutário, disciplinado em referida lei (artigo $1^{\circ}$ ).

32 Dispõe o inciso II do artigo 37 da Constituição Federal (in verbis): " $I I-$ a investidura em 
lugar, referida aproximação decorre da impossibilidade de exoneração a qualquer tempo e sem motivação de servidores e empregados públicos.

Se a Constituição Federal expressamente determina ser necessária a aprovação em concurso público para a investidura em emprego ou cargo público, não poderia ser admissível que servidores e empregados públicos fossem a qualquer tempo desligados de suas funções. A diferença entre empregados e servidores públicos reside, contudo, na previsão expressa da impossibilidade de livre exoneração dos servidores públicos na Constituição Federal (artigo $41, \S 1^{\circ}$ ), sem que haja qualquer previsão semelhante acerca dos requisitos para o desligamento dos empregados públicos.

Entretanto, a ausência de previsão constitucional expressa para o processo de desligamento dos empregados públicos não pode, em hipótese nenhuma, ser interpretada no sentido de tolher a estabilidade de que tais empregados gozam. Interpretação em sentido contrário aniquilaria em absoluto a observância dos Princípios da Isonomia e da Impessoalidade na Administração Pública, o que feriria escandalosamente o caput do artigo 37 e o caput do artigo $5^{\circ}$ da Constituição Federal, uma vez que a possibilidade de livre demissão dos empregados públicos permitiria que os administradores das empresas estatais (gestores de coisas públicas. em todos os casos) livremente escolhessem quais serão os empregados que permanecerão em tais entidades e quais serão demitidos, despindo de qualquer utilidade prática a realização prévia de concurso público.

Com a lucidez habitual, o mestre Celso Antônio Bandeira de Mello, corroborando o entendimento acima exposto, ensina que "assim como a contratação de pessoal nas empresas públicas e sociedades de economia mista sofre o condicionamento aludido, também não é livre o desligamento de seus empregados. Cumpre que haja razões prestantes e demonstráveis para efetuá-lo, já que seus administradores não gerem negócio particular, onde prepondera o princípio da autonomia da vontade, mas conduzem assunto de interesse de toda a coletividade, cuja gestão sempre reclama adscrição à finalidade legal preestabelecida, exigindo, pois, transparência, respeito à isonomia e fundamentação satisfatória para os atos praticados. Dai que a despedida de empregado demanda apuração regular de suas insuficiências ou faltas, com direito à defesa e, no caso de providências amplas de enxugamento de pessoal, prévia divulgação dos critérios que presidirão as dispensas, a fim de que se possa conferir a impessoalidade das medidas concretamente tomadas" 33

Portanto, considerando-se que o regime constitucional vigente, em primeiro lugar, aproximou significativamente os regimes de emprego e cargo público, visto exigir a realização de concurso público previamente à investidura de ambos e impossibilitar a livre exoneração de ambos, e, em segundo lugar, não veda ou cerceia,

cargo ou emprego público depende de aprovação em concurso público de provas ou de provas e títulos, de acordo com a natureza e a complexidade do cargo ou emprego, na forma prevista em lei. ressalvadas as nomeações para cargo em comissão declarado em lei de livre nomeação e exoneração".

33 MELLO, Celso Antônio Bandeira de. Curso, op. cit. Página 260. 
de forma alguma, a utilização de empregos públicos para o exercício de qualquer atividade a ser desempenhada pela Administração Pública, entendemos que a mera existência de regime de emprego público (regido pela Consolidação das Leis Trabalhistas) nas empresas estatais não configura razão bastante para rejeitar a possibilidade de empresas estatais exercerem atividades da Administração Ordenadora ${ }^{34}$.

Passada esta questão, deparamo-nos com as definições de empresas públicas e sociedades de economia mista contidas no Decreto-Lei 200/67 (transcritas no item II acima), que, em princípio, poderiam inviabilizar a adoção da forma societária para o desempenho de funções públicas.

Conforme já categoricamente afirmamos no item II deste estudo, as definições contidas em referido diploma legal de empresas públicas e sociedades de economia mista são errôneas e não designam tais entidades corretamente, pois a elas referem-se como entidades constituídas exclusivamente para a exploração de atividade econômica "que o Governo seja levado a exercer por força de contingência ou conveniência administrativ'a".

Diante da qualificação do termo "atividade econômica" contida na definição apresentada pelo Decreto-Lei 200/67, parece-nos ser absolutamente clara a referência às atividades econômicas em sentido estrito, o que, conseqüentemente, exclui os serviços públicos, pois o governo não pode "ser levado" a prestar serviços públicos (atividades econômicas em sentido amplo) por conta de contingência ou conveniência administrativa, visto serem os serviços públicos obrigações precípuas do Poder Público.

Sendo assim, a definição legal das empresas públicas e sociedades de economia mista simplesmente exclui ipso facto a possibilidade da constituição de referidas entidades para a prestação de serviços públicos, o que torna a adoção de tal definição absolutamente imprópria para abalizar a análise do papel das empresas públicas ou sociedades de economia mista, visto ser a maioria destas prestadoras de serviços públicos e não exploradoras de atividades econômicas em sentido estrito.

Todavia, o erro contido na definição legal das empresas públicas e sociedades de economia mista não se configura argumento bastante para simplesmente afirmarmos que poderá haver empresas estatais exercentes de funções públicas. É preciso encontrar outros argumentos que respaldem a possibilidade da existência das empresas estatais exercentes de funções públicas.

34 É importante mencionar que o argumento ora exposto não foi aceito pelo Ministro Marco Aurélio Mello em decisão liminar proferida em Ação Direta de Inconstitucionalidade (ADIn 2.310) na qual se questionou a adoção de empregos públicos para os servidores das agências reguladoras (artigo $1^{\circ}$ da Lei 9.986 , de 18 de julho de 2000). Remissa máxima vênia, não vimos em referida decisão qualquer argumento. nem tampouco o apontamento de qualquer dispositivo constitucional efetivamente ferido. que possam acarretar a inconstitudonalidade da adoção de empregos públicos para a realização de atividades da Administração Ordenadora Assim, não entendemó y a a decisão cm comento possa prejudicar o entendimento aqui exposto no sentido da legalidade da adoção de empregos públicos para a realização de tais atividades, em função da aproximação constitucional dos regimes dos empregos e cargos públicos. 
Por força de expresso mandamento constitucional, a constituição de empresa pública ou sociedade de economia mista deverá, necessariamente, ser autorizada por lei específica (inciso XIX do artigo 37 da Constituição Federal). É indubitável que a lei que autorizar a constituição de uma empresa estatal deverá estabelecer claramente qual o seu objeto social e suas formas de atuação, sob pena de invalidade da lei autorizadora, uma vez que não é permitida a existência de uma autorização genérica à Administração para constituir a empresa estatal que bem entender ${ }^{35}$.

Desta forma, em âmbito federal, a questão da incompatibilidade da definição de empresas públicas e sociedades de economia mista contida no Decreto-Lei 200/67 com a possibilidade de constituir-se empresas estatais para o exercício de funções públicas está resolvida, pois haverá sempre uma lei (norma da mesma hierarquia do Decreto-Lei 200/67) que determine se a empresa estatal explorará atividade econômica em sentido estrito, prestará serviço público ou exercerá função pública, ficando, portanto, por conta do princípio da especificidade das normas, afastadas as definições contidas no artigo $5^{\circ}$ do Decreto-Lei $200^{36}$.

Quanto à situação dos Estados, do Distrito Federal e dos Municípios, a solução da questão da aplicabilidade da definição do Decreto-Lei 200/67 pode ser ainda mais facilmente encontrada. Isto ocorre, pois o Decreto-Lei 200/67 é norma aplicável exclusivamente à Administração Pública federal, sendo as definições contidas no artigo $5^{\circ}$ de tal norma aplicáveis exclusivamente à União Federal, conforme disposição expressa do artigo $4^{\circ}$ de referido diploma normativo. É dizer, o Decreto-Lei 200/67 é norma federal e não norma nacional, visto que sua aplicação restringe-se à União Federal. Desta forma, os Estados, o Distrito Federal e os Municípios, que não se encontram vinculados pelas definições contidas no Decreto-Lei 200/67, não enfrentam quaisquer restrições à constituição de empresas públicas para o exercício de funções públicas.

Diante do raciocínio acima desenvolvido, podemos concluir que o Poder Público poderá, com base em razões de conveniência e oportunidade, constituir empresas estatais para o exercício de funções públicas ${ }^{37}$. Todavia, tal poder deverá, necessariamente, observar alguns limitadores, que passaremos a desenvolver neste ponto.

O primeiro limitador existente, segundo nosso entendimento, consta da total e absoluta impossibilidade do ingresso de capitais privados nas empresas estatais que

35 Com relação à impossibilidade de autorização genérica à constituição de empresas estatais, afirma Celso Antônio Bandeira de Mello: "o Legislativo não pode conferir autorização genérica ao Executivo para instituir tais pessoas. É preciso que a lei designe nomeadamente que entidade pretende gerar. que escopo poderá por ela ser cumprido e quais as atribuiçôes que para tanto lhe confere." In Curso op. cit. Página 164

36 Apenas a título de exemplo. é possivel mencionarmos a Lei 10.847, de 15 de março de 2004 , que autorizou a União Federal a constituir a Empresa de Pesquisa Energética - EPE com a finalidade de realizar as pesquisas e estudos necessários ao planejamento da expansão do setor elétrico nacional, o que. inquestionavelmente. não se pode configurar nem como atividade econômica em sentido estrito, nem como serviço público.

37 Sobre esta questão, é forçoso conferir magistral trabalho do ilustre Prof. Carlos Ari Sundfeld intitulado "Empresa Estatal pode exercer o Poder de Polícia", publicado no Boletim de Direito Administrativo de Fevereiro de 1993, nas páginas 98 e seguintes. 
exercem funções públicas. Vale dizer, não se pode, em nenhuma hipótese, admitir a existência de uma sociedade de economia mista que exerça funções públicas, mas apenas de empresas públicas.

Entendemos ser o efetivo ingresso de capitais privados um limitador à existência de empresa estatal exercente de função pública por conta de eventual conflito de interesse que poderá existir na administração da empresa, pois a minoria privada poderá interferir no correio exercício das atividades da empresa. notadamente com relação àquelas atividades pertencentes à Administração Ordenadora. Nos termos da lei societária, os acionistas minoritários sempre poderão ter o direito de participar da gestão da empresa, inclusive mediante a participação no Conselho de Administração e, por conta disso. a existência de acionistas minoritários privados poderá provocar conflitos de interesses na gestão de interesses públicos (artigo 141 da Lei 6.404/76).

Ademais, até este momento, fundamentamos a possibilidade da adoção da forma societária para o exercício de funçôes públicas por conta das inquestionáveis semelhanças fáticas existentes entre as empresas públicas e as autarquias. Ora, se considerarmos que o ingresso efetivo de capitais privados, que importa em maior influência do regime de direito privado, é aceitável para as empresas estatais que exercem funções públicas. toda argumentação sustentada no sentido da semelhança entre empresas públicas e autarquias será perdida, uma vez as autarquias jamais poderão aceitar a presença de capitais privados, por serem pessoas de direito público.

Deve-se ressaltar, contudo, que a limitação ora exposta não se aplica às ditas sociedades de economia mista, cuja integralidade do capital, com exceção das ações detidas excepcionalmente pelos conselheiros, é detida pelo Poder Público. Conforme já afirmamos anteriormente (item II acima), estas "sociedades de economia mista" são, em verdade, empresas públicas, visto que a totalidade das ações apenas não pertence ao Poder Público por força de expressa disposição legal.

O segundo limitador que vislumbramos para a possibilidade das empresas públicas exercerem funções públicas consta da impossibilidade de tais entidades exercerem simultaneamente funções públicas e atividades econômicas em sentido estrito em regime de concorrência com a iniciativa privada. Tal limitador é devido à evidente violação ao Princípio da Isonomia. uma vez que o Poder Público, ao explorar atividades em sentido estrito em regime de concorrência com a iniciativa privada. sujeita-se às mesmas normas aplicáveis à iniciativa privada, por força de expressa disposição constitucional (artigo 173). Assim, tendo em vista a igualdade de condições constitucionalmente obrigatória, entendemos que as empresas públicas que exercem funções públicas não poderão, em nenhum caso, explorar atividades econômicas em sentido estrito.

Face às idéias aqui expostas, poder-se-ia pensar que defendemos o abandono do modelo autárquico para que as funções públicas passem a ser desenvolvidas exclusivamente por empresas públicas. Porém, tal assertiva seria totalmente incorreta, pois com este estudo procuramos apenas fundamentar a possibilidade e a legalidade de empresas públicas exercerem funções públicas, sem que tenhamos advogado pela idéia da adoção desta ou daquela forma para as entidades que exercem funçōes públicas. 
A adoção da forma societária traz consigo uma série de consequiências, tais como a obrigatoriedade de registro e publicação de atos societários perante o registro do comércio competente e a competência da justiça trabalhista para resolução das questões lavorais. Da mesma forma, a adoção da forma autárquica também traz consigo uma série de consequências, tais como a existência de regime estatutário para seus servidores. Desta forma, caberá à Administração Pública, com base em critérios de conveniência e oportunidade, determinar qual a melhor forma a ser adotada diante da função da Administração Ordenadora a ser exercida, que contempla um plexo relativamente grande e complexo de atividades típicas da Administração.

\section{Regime Jurídico Aplicável às Empresas Estatais}

Definir o regime jurídico aplicável às empresas estatais nada mais é do que procurar definir se sobre elas recairá mais intensamente um regime de direito público ou um regime de direito privado. Afirmamos no início deste trabalho (item II acima) que as empresas estatais são pessoas de direito privado, com regime jurídico híbrido entre o direito privado e o direito público, devendo tal hibridez variar conforme a atividade realizada pela empresa estatal em análise. Assim, teremos por escopo neste tópico analisar quando haverá maior incidência do regime de direito público e quando haverá maior incidência do regime de direito privado sobre as empresas estatais.

A incidência maior de um regime jurídico de direito público acarretará menor liberdade às empresas estatais no exercício de suas atividades, pois haverá incidência de todas as normas que comandam a Administração Pública (obrigatoriedade de realização de licitações salvo nas hipóteses expressamente previstas em lei, por exemplo), mas, em contrapartida, acarretará uma supremacia da empresa estatal em questão sobre as demais pessoas privadas, uma vez que, como entidade regida pelas normas da Administração Pública, serão aplicáveis a referida entidade os Princípios da Supremacia do Interesse Público sobre o Interesse Privado e o da Indisponibilidade do Interesse Público.

Por outro lado, a incidência maior de um regime jurídico de direito privado acarretará maior liberdade à empresa estatal na condução de seus negócios, pois haverá maior aplicabilidade do Princípio da Autonomia da Vontade, sem que haja, em contrapartida, qualquer supremacia da empresa estatal sobre as demais pessoas de direito privado, uma vez ambas aluarão em regime de estrita concorrência.

Diante das conseqüências da existência de um regime de direito público ou de um regime de direito privado, é fundamental ter-se bastante claramente estabelecido quando deverá haver a incidência preponderante de um e de outro regimes, sob pena de violações aos princípios fundamentais que regem a Administração Pública, a Ordem Econômica e os direitos dos particulares ${ }^{38}$, sobretudo quando se tratar das empresas estatais exploradoras de atividades econômicas.

38 Neste sentido, afirma Thomas Vollmöller: "O Estado, com as empresas estatais, participa da vida econômica e assim inicia concorrência com seus cidadãos. Ele o faz sob condições especiais, 
Sendo assim, passaremos a procurar encontrar um critério para a definição de um regime jurídico a prevalecer no regimento das empresas estatais em função de suas atividades. Para tanto, a classificação das empresas estatais longamente acima exposta afigura-se-nos ferramenta bastante eficiente.

Ao classificarmos e distinguirmos as empresas estatais, vimos claramente três formas distintas, quais sejam, (i) as empresas estatais prestadoras de serviços públicos, (ii) as empresas estatais exploradoras de atividades econômicas, e (iii) as empresas estatais que exercem funções públicas, ou seja, aquelas funções públicas relacionadas à Administração Ordenadora.

Não há dúvidas de que as atividades realizadas pelas primeiras sujeitam-se, preponderantemente, a um regime de direito público, visto serem funções precípuas do Poder Público. De outra forma, também não restam dúvidas de que as atividades realizadas pelas segundas sujeitam-se, preponderantemente, a um regime de direito privado, visto serem atividades constitucionalmente reservadas à iniciativa privada. Por fim, quanto às terceiras, não há nem que se cogitar a preponderância de outro regime que não o de direito público para suas atividades, posto serem tais atividades exclusivas do Poder Público ${ }^{39}$.

À luz de tais colocações, torna-se bastante simplificada a tarefa de encontrar-se um regime jurídico às empresas estatais, uma vez que o grau de influência do regime de direito público sobre o regime de direito privado guardará sempre estrita relação com a atividade desenvolvida pela empresa estatal sub examine.

\section{IV.1. Empresas Estatais que Exercem Funções Públicas}

Quanto às empresas estatais que exercem funções públicas, o regime jurídico aplicável será praticamente integralmente o regime de direito público, sendo o regime de direito privado exclusivamente aplicável para os requisitos de sua constituição, visto ser pessoa jurídica de direito privado, e para o regimento de suas relações lavorais. Assim, estas empresas estatais, por exercerem funções típicas e exclusivas de Estado, têm sobre si incidente um regime essencialmente semelhante àquele incidente sobre o próprio Estado, devendo, por exemplo, realizar licitações anteriormente a todas as suas contratações, exceto nos casos expressamente previstos em lei, bem como observar a todos os demais dispositivos constantes do artigo 37 da Constituição Federal.

\section{IV.2. Empresas Estatais Prestadoras de Serviços Públicos}

Da mesma forma, as empresas estatais prestadoras de serviços públicos terão sobre si incidente regime jurídico preponderante de direito público, vez que exercem

como poder de financiamento ilimitado, fundamental deslealdade concorrencial e a possibilidade de condicionar-se tanto com normas de direito privado, quanto com normas de direito público. Com isso, forma-se a questāo acerca da possibilidade e dos limites das tarefas econômicas próprias." In Die Wirtschaftliche, op. cit. Página 145

39 A respeito de tal distinção de regimes, conferir GORDILLO, Augustín. Tratado, op. cit. Tomo 1. Página XIV-16 e ss. 
funções típicas de Estado. Portanto. partindo exatamente do mesmo pressuposto de que partimos ao analisar o caso das empresas estatais exercentes de funções públicas, entendemos que a grande maior parte das normas que regem as atividades do Estado deverão ser pari passu aplicáveis às empresas estatais prestadoras de serviços públicos.

Todavia, entendemos que o regime de direito público incidente sobre as empresas estatais prestadoras de serviços públicos poderá ser relativamente abrandado nas hipóteses em que referidas empresas exerçam atividades econômicas em sentido estrito, o que, conforme passaremos a expor, parece-nos possível.

\section{IV.2.1. Serviços Públicos e Atividades Econômicas Reguladas}

A Constituição Federal de 1988 passou a prever, nos incisos XI e XII de seu artigo 21 , a possibilidade de outorga de autorizações para a realização de atividades consideradas serviços públicos (telecomunicações e energia elétrica, por exemplo). Contudo, o artigo que regula a outorga de privilégios para a prestação de serviços públicos (artigo 175) previu apenas duas formas de outorga, quais sejam, a concessão e a permissão. Diante deste fato, muito se questiona se poderá haver a outorga de serviços públicos por meio de autorizações ou se as autorizações predicam a existência de atividades privadas exercidas no mesmo segmento de serviços públicos.

Ficamos com o segundo entendimento, pois entendemos que o legislador constituinte, ao se referir à autorização, previu a possibilidade de outorga de atividades econômicas em sentido estrito exploradas no mesmo ramo industrial dos serviços públicos, mediante mera autorização do Poder Público ${ }^{40}$.

Dizemos que as sobreditas atividades são atividades econômicas em sentido estrito e não serviços públicos por conta da atenuação do regime de direito público incidente sobre tais atividades, uma vez que os exploradores das atividades arroladas nos incisos XI e XII do artigo 21 da Constituição Federal em regime de autorização não se sujeitam às normas aplicáveis aos prestadores de serviços públicos em regime de concessão ou permissão, tais como determinação do valor das tarifas a serem cobradas dos usuários, metas de universalização e obrigação de prestação contínua dos serviços.

40 Exatamente este é o entendimento de Alexandre Santos de Aragão, que afirma "ao se referir à prestação de serviços públicos mediante autorização, a Constituição incluiu entre os serviços públicos atividades nāo titularizadas pelo Poder Público. Apenas a concessão e a permissão transferem a particulares a execução de serviços públicos de titularidade estatal. As autorizaçōes são instrumentos de ordenação pública de atividades de titularidade privada." In Agências Reguladoras e a Evolução do Direito Administrativo Econômico. la edição - 2002. Ed. Forense. Rio de Janeiro. Página 151. Na mesma linha de argumentação, segue Dinorá Musetti Grotti ao afirmar que "o regime de autorização estaria a demonstrar que alguns dos serviços elencados no artigo 21 (incisos XI e XII) e 223 poderão ser prestados em regime de direito privado, típico das atividades econômicas, constituindo atividade econômica em sentido estrito, enquanto os demais, sujeitos ao regime de concessão ou permissão, seriam serviços públicos." In O Serviço Público e a Constituição Brasileira de 1988. $1^{2}$ edição - 2003. Ed. Malheiros. São Paulo. Página 163 e ss. 
Como exemplo de tais atividades. podemos mencionar os serviços de telecomunicações prestados em regime de direito privado nos termos dos artigos 126 e seguintes da Lei 9.472 , de 16 de julho de 1997 , bem como a geração de energia elétrica em regime de produção independente, prevista nos artigos de seguintes da Lei 9.074 , de 7 de julho de $1995^{4 !}$.

Desta forma, as empresas estatais prestadoras de serviços públicos que, porventura, explorem as atividades previstas nos incisos XI e XII da Constituição Federal em regime de autorização terão, exclusivamente no que concerne a tais atividades, uma certa relativização do regime de direito público e uma maior influência do regime de direito privado.

Apenas para aclarar o entendimento aqui expresso, podemos mencionar o exemplo de uma empresa estatal prestadora de serviços públicos de energia elétrica que controle uma usina termelétrica autorizada como produtora independente de energia elétrica. Neste caso, o regime incidente sobre a atividade de geração independente de energia elétrica será mais aproximado do direito privado, pois a atividade exercida é atividade econômica em sentido estrito.

\section{IV.3. Empresas Estatais Exploradoras de Atividade Econômicas}

Por fim, quanto às empresas estatais exploradoras de atividades econômicas, é possível afirmar-se que o regime jurídico aplicável será o mais aproximado do direito privado possível. Afirmamos isso, pois as empresas estatais exploradoras de atividades econômicas atuam em regime livre de concorrência com a iniciativa privada (com exceção daquelas exploradoras de monopólios), não sendo possível, portanto. admitir-se que lhes seja tolhida a agilidade negociai essencial ao desenvolvimento de suas atividades, nem tampouco que lhes seja atribuída a supremacia típica do Poder Público, pois aqui não falamos em atividades precípuas do Poder Público.

Sendo assim, entendemos que as empresas estatais exploradoras de atividades econômicas em sentido estrito não poderão ter sobre si o mesmo regime jurídico incidente sobre as empresas estatais prestadoras de serviços públicos e exercentes de funções públicas, visto que atuam em regime de livre concorrência com a iniciativa privada e não exercem funções típicas do Estado. A própria Constituição Federal, em seu artigo 173, inciso II, expressamente distingue o regime jurídico aplicável às empresas estatais exploradoras de atividades econômicas, afirmando que este deverá

41 Produtor Independente de Energia Elétrica é definido pelo artigo 11 da Lei 9.074/95. como: " a pessoa jurídica ou pessoas reunidas em consórcio que recebam concessão ou autorização do pode concedente, para produzir energia elétrica destinada ao comércio de toda ou parte da energia produzida por sua conta e risco". Sem qualquer prejuízo da definição legal ora mencionada, é importante ressaltar que o caráter de atividade econômica em sentido estrito da produção independente de energia elétrica foi relativamente flexibilizado quando da edição da Lei 10.848 , de 15 de março de 2004. uma vez que o produtor independente de energia elétrica passará a sujeitar-se menos a sua autonomia de vontade e mais a determinações do Governo Federal, estabelecidas com vistas ao planejamento do Setor Elétrico, consoante previsto no Decreto $n^{\circ}$ Decreto $n^{\circ} 5.163$, de 30 de junho de 2004. 
ser aquele próprio das empresas privadas, inclusive quanto às obrigações comerciais, trabalhistas e tributárias.

Neste sentido, afigura-se, a nosso ver, inconstitucional o parágrafo único do artigo $1^{\circ}$ da Lei 8.666/93, que determina que o regime de contratação e licitação das empresas estatais (inclusive as exploradoras de atividades econômicas em sentido estrito) será o mesmo aplicável a todos os demais órgãos e entidades controlados pelo Poder Público, uma vez que tal dispositivo equipara indevidamente aquilo que o legislador constitucional expressamente distingüiu ${ }^{42}$.

Caio Tácito corrobora nossa posição ao afirmar que "ressalvadas as exceções expressas em lei, as empresas do Estado, constituidas como sociedades comerciais, devem regular-se pelas normas de direito privado, que lhe são próprias. Pretender equipará-las, em seu regime jurídico, aos órgãos da administração direta, ou autárquica é violar a lei, ignorando a escolha de regime jurídico diverso que visa, precipuamente, a fugir dos embaraços administrativos que se encontram no pretenso paradigma, do qual o legislador deliberadamente se afastou" ${ }^{43}$.

Ademais, a expressa distinção do regime jurídico aplicável às empresas estatais prestadoras de serviços públicos e às empresas estatais exploradoras de atividades econômicas em sentido estrito, tal como existente na Constituição Federal, é, igualmente. verificada no Direito Comunitário Europeu, uma vez que o item l do artigo 86 do Tratado de Constituição da Comunidade Européia expressamente determina que todas as restrições a práticas anticoncorrenciais e monopólios previstas em tal

42 Neste sentido, afirma Maria Sylvia Zanella Di Petro: "Não foi, evidentemente, a melhor opção, tendo em vista que as empresas estatais que exercem atividades econômicas, muitas vezes em regime de competiçāo com a iniciativa privada, além de submeter-se ao rígido procedimento da licitação, ainda detinham prerrogativas próprias de autoridade pública, como os poderes de alterar e rescindir unilateralmente os contratos, o de exigir garantias, o de aplicar penalidades etc. Enfim, empresas estatais detinham supremacia sobre outras empresas privadas." In Empresas Estatais. Submissāo à Lei $n^{\circ}$ 8.666/93. Aspectos Juridicos-Constitucionais. In DI PIETRO, Maria Sylvia Zanella. Temas Polêmicos Sobre Licitações e Contratos. $5^{a}$ edição - 2002. Ed. Malheiros. São Paulo. Página 25. Mesmo é o entendimento de Marçal Justen Filho, que afirma: "A disciplina das contrataçōes administrativas deve ser compativel com o funcionamento eficiente das organizaçōes administrativas. Logo, as entidades que desenvolvem atividade econômica não podem sujeitar-se ao mesmo regramento licitatório previsto para a Administração direta e autárquica. Isso é incompativel com os próprios fins buscados por elas e acarreta frustraçāo de sua comperitividade no mercado. Enquanto os demais agentes econômicos privados realizam contratações segundo o ritmo de suas necessidades e sob sigilo absoluto (quando necessário), as pessoas da Administração indireta são dísciplinadas pelo regime padrão da Lei $n^{\circ}$ 8.666/93. Uma das reformas essenciais do sistema de licitações públicas reside nesse ponto. É imperioso diferenciar o regime de licitações entre as pessoas integrantes da Administração Pública. A sistemática padrão da Lei 8.666/93 não pode ser aplicada à Administração direta e autárquica. Também as entidades administrativas prestadoras de serviços públicos podem sujeitar-se ao mesmo regime. Mas as pessoas que desempenham atividade econômica têm de ser submetidas a regime distinto. Isso não significa liberá-las das regras sobre licitação e publicidade, mas adotar disciplina mais simples, dinâmica e compativel com a natureza de sua atuação." In Comentários à Lei de Licitações e Contratos Administrativos. $8^{\text {a }}$ edição - 2001. Ed. Dialética. São Paulo. Página 23.

43 TÁCITO, Caio. Direito Administrativo. la Edição - 1975. Ed. Saraiva. São Paulo. Página 174. 
tratado aplicar-se-ão também às empresas estatais controladas pelos países-membros. Ao mesmo tempo, o item 2 do mesmo artigo expressamente determina que àquelas empresas estatais que prestam serviços de interesse econômico geral (serviços públicos, por assim dizer, em que pese tal conceito não existir em todos os países da Comunidade Européia) o disposto no item l somente será aplicável na medida em que não haja qualquer prejuízo às atividades realizadas por tais empresas, o que implica em importantíssima restrição da aplicabilidade das regras gerais de concorrência a serem aplicadas às empresas estatais exploradoras de atividades econômicas em sentido estrito ${ }^{44}$.

Este simples exemplo do direito comparado serve para corroborar ainda mais a impossibilidade de equiparação dos regimes jurídicos aplicáveis às empresas estatais exploradoras de atividades econômicas em sentido estrito e às empresas estatais prestadoras de serviços públicos, tal como adotado pela Lei 8.666/93.

\section{Natureza dos Bens das Empresas Estatais}

Outra questão que merece breve análise relativa às empresas estatais é a natureza de seus bens. Vale dizer, diante das considerações acima apresentadas, é importante analisarmos se os bens integrantes do patrimônio das empresas estatais configuramse como bens públicos e, portanto, são consagradores do regime jurídico específico dos bens públicos (inalienabilidade, imprescritibilidade, etc.) ou se referidos bens são bens privados, sujeitos às disposições das normas de direito privado, portanto.

No direito brasileiro, a determinação de quais os bens públicos, bem como do regime a eles aplicável é prevista no Código Civil (artigos 98 e ss.). Segundo as disposições de tais artigos, os bens públicos são todos aqueles pertencentes às pessoas jurídicas de direito público, sendo classificados como (i) bens públicos de uso comum, que são aqueles bens públicos disponíveis ao uso de toda a gente, (ii) bens públicos de uso especial, que são aqueles que dão suporte ao exercício de determinada função ou serviço público e (iii) bens públicos de uso dominical, que são aqueles sem qualquer afetação pública, mas pertencentes a uma pessoa de direito público.

À luz da classificação e da sistemática adotadas no Código Civil, poderíamos entender que os bens das empresas estatais são bens privados, visto que pertencem a pessoas de direito privado, quais sejam, as empresas estatais (vide item II acima). Contudo, tal assertiva, quando generalizada a todas e quaisquer empresas estatais, não nos parece correta.

Quanto às empresas estatais exploradoras de atividades econômicas em estrito senso, não há muito o que se questionar, posto que, conforme expusemos acima, o regime jurídico aplicável a tais entidades deverá ser o mais aproximado possível do regime jurídico aplicável às pessoas de direito privado. Assim, os bens de tais entidades, que não têm nenhuma afetação a uma função ou a um serviço público,

44 Cf. STREINZ, Rudolf. Europarecht. $6^{a}$ edição - 2003. Ed. C. F. Muller. Heideiberg. Página 363. 
estarão integralmente sujeitos a um regime de direito privado. $\mathrm{O}$ mesmo se aplica aos bens de empresas estatais prestadoras de serviços públicos que explorem atividades econômicas em sentido estrito em seus respectivos segmentos (por exemplo, os bens vinculados à geração independente de energia termelétrica).

Todavia, distinta será a situação das empresas estatais que prestam serviços públicos ou que exercem funçōes públicas, uma vez que os bens de referidas empresas estarão sempre afetados a uma determinada função ou serviço público. No caso das empresas estatais prestadoras de serviços públicos, parece-nos ser esta questão bastante pacífica, uma vez que a própria lei de concessões federal (Lei $8.987 / 95$ ), no inciso VI de seu artigo $7^{\circ}$, faz expressa alusão aos bens afetados à prestação de um serviço público como bens públicos ${ }^{45}$. Em que pese não haver disposição legal específica, outra não poderá ser a situação das empresas estatais que exercem funções públicas, pois, conforme mencionamos acima, o regime a elas aplicável será o mais aproximado o possível do regime de direito público, o que, por via de consequêencia, se aplica a seus bens, posto que estes suportam o exercício de função típica e essencial da Administração.

Sendo assim, entendemos que apenas os bens das empresas estatais destinados à exploração de atividade econômica em sentido estrito estarão sujeitos a um regime de direito privado (afastado, portanto, o regime jurídico aplicável aos bens públicos). Os demais bens das empresas estatais, essenciais à prestação de um serviço público ou ao exercício de uma função pública, estarão sujeitos a um regime de direito público, sob pena de violação ao Princípio da Continuidade dos Serviços Públicos e das Atividades Administrativas.

\section{Empresas Estatais e Regulação Econômica}

Todo processo de transformação das atividades das empresas estatais acima mencionado está intrinsecamente relacionado com uma severa alteração na forma do Estado conduzir suas atividades. Vale dizer, o Estado brasileiro (assim como a grande maior parte dos Estados ocidentais) não deixa de intervir no domínio econômico por meio das empresas estatais sem realizar qualquer outra atividade intervencionista.

Muitíssimo pelo contrário. Os processos de privatização conduzidos no Brasil, ocorridos quase que concomitantemente com a criação de diversos órgãos reguladores, marcam a transformação do Estado brasileiro de um Estado-Providência para

45 Neste sentido, afirma Maria Sylvia Zanella Di Pietro: "Esses bens estão submetidos a regime jurídico de direito público, da mesma forma que os bens de uso comum do povo e os bens de uso especial, referidos no artigo 66 do Código Civil. Eles incluem-se na categoria de bens extra comercium. ainda que a lei não o diga expressamente; trata-se de característica inerente ao principio da continuidade do serviço público. Como conseqüência, tais bens estão fora do regime jurídico privado, não podendo ser objeto de relaçōes jurídicas regidas pelo direito civil ou comercial." In Parcerias na Administração Pública. $4^{\mathbf{a}}$ ediçāo - 2002. Ed. Atlas. São Paulo. Página 91. 
um Estado-Regulador, no qual o Estado deixa de realizar certas atividades e passa simplesmente a regular sua realização pela iniciativa privada. A retirada do Estado da direta prestação de serviços e exploração de atividades econômicas tem como conseqüência direta a assunção, pelo Estado, da atividade reguladora, tanto no campo dos serviços públicos. quanto no campo de atividades econômicas relevantes para a coletividade 46 .

De forma praticamente concomitante com a constituição de órgãos reguladores para determinados setores da economia (as denominadas agências reguladoras ${ }^{47}$ ), foi modernizado e fortalecido no Brasil o sistema de regulação da concorrência e repressão às infrações à Ordem Econômica, por meio da Lei 8.884, de 11 de junho de 1994, cujo escopo foi transformar o Conselho Administrativo de Defesa Econômica em autarquia federal vinculada ao Ministério da Justiça, bem como definir claramente sua esfera de atuação.

Neste contexto, merece análise o papel das empresas estatais existentes diante da nova estrutura estatal de intervenção no domínio econômico. É dizer, com a nova forma intervencionista do Estado na economia, realizada por meio da regulação econômica, estariam as empresas estatais sujeitas à regulação estatal ou não? Para respondermos a esta questão, analisaremos em primeiro lugar a submissão das empresas estatais à regulação setorial e, na sequiência, a submissão das empresas estatais às regras de regulação da concorrência.

Preliminarmente, é importante mencionarmos que a análise ora exposta não incluirá as empresas estatais que exercem funções públicas, uma vez que tais empresas (i) não exercem funções sujeitas à regulação estatal, pois são atividades típicas e exclusivas de Estado, e (ii) atuam, muitas vezes, como agentes reguladores em determinados setores, através do exercício de atividades da Administração Ordenadora (por exemplo, a Empresa Metropolitana de Transportes Urbanos de São Paulo. que fiscaliza a prestação dos serviços de transporte coletivo em regiões metropolitanas por meio de autorizações).

Em primeiro lugar, parece-nos relativamente clara a submissão das empresas estatais exploradoras de atividades econômicas em sentido estrito à regulação estatal

46 Cf. JUSTEN FILHO. Marçal. O Direito, op. cit. Páginas 29 e ss.

47 No direito italiano, as agências reguladoras podem ser definidas como: "entes e órgãos páblicos dotados de substancial independência do Governo. caracterizada pela autonomia organizacional. financeira e contábil e pela ausência de controle e de sujeição ao poder de estabelecer diretrizes do Poder Executivo. gozando de garantia de autonomia na nomeação, no estabelecimento dos requisitos subjetivos e na duração do mandato dos dirigentes. e de ter como função a tutela de interesses constitucionais em campos socialmente relevantes" In DELPINO. L. / GIUDICE. F. dei / CARINGElla. F. Compendio de Diritto Ammiinistrativo. $13^{\mathrm{a}}$ edição - 2003. Ed. Edizione Simone. Nápoles. Página 215. Entre nós, podemos mencionar a definição apresentada por Alexandre Santos de Aragão, segundo a qual as agências são "autarquias de regime especial, dotadas de considerável autonomia frente à Administração centralizada, incumbida do exercício de funções regulatórias e dirigida por colegiada cujos membros são nomeados por prazo determinado pelo Presidente da República. após prévia aprovação pelo Senado Federal, vedada a exoneração ad nutum." In Agências, op. cit. Página 275. 
nos setores em que atuam, visto que, conforme já mencionamos, tais empresas atuam em regime de livre concorrência com a iniciativa privada.

Em determinados casos, a submissão das empresas estatais à regulação pública é expressa em lei. Tal é o caso (i) da Petróleo Brasileiro S.A. - Petrobras, que, por força expressa do artigo $8^{\circ}$ e do $\S 1^{\circ}$ do artigo 61 da Lei 9.478/97, sujeita-se à regulação setorial imposta pela Agência Nacional do Petróleo, (ii) das instituições financeiras públicas, que, por força do artigo inciso IX do artigo 10 da Lei 4.595 , de 31 de dezembro de 1964, encontram-se sujeitas à regulação setorial exercida pelo Banco Central do Brasil, autarquia federal incumbida de regular e fiscalizar as atividades bancárias no Brasil ${ }^{48}$, e (iii) de farmácias instituídas e controladas pelo Poder Público com a função de fornecer medicamento com descontos para a população carente, que, inquestionavelmente, estarão sujeitas à regulação e à fiscalização exercida pela Agência Nacional de Vigilância Sanitária, nos termos do inciso II do artigo $2^{\circ}$ da Lei 9.782 , de 26 de janeiro de 1999.

Assim, no caso das empresas estatais exploradoras de atividades econômicas em sentido estrito, entendemos que sempre haverá sujeição à regulação estatal, da mesma forma a que estão sujeitas a tal regulação as empresas privadas atuantes em concorrência com referidas empresas estatais, sob pena de violação ao Princípio da Isonomia, previsto no caput do artigo $5^{\circ}$ da Constituição Federal.

A questão mais relevante, todavia, colocar-se-á na análise do caso das empresas estatais prestadoras de serviços públicos. Conforme mencionamos acima, parte relevante das agências reguladoras foi constituída para a regulação e fiscalização de serviços públicos prestados em regime de concessão ou permissão por particulares, bem como de atividades econômicas em sentido estrito desenvolvidas nos mesmos campos de determinados serviços públicos (vide item IV.2.1 acima). Ademais, é apenas no campo da regulação dos serviços públicos que existem agências reguladoras nos âmbitos estadual e municipal ${ }^{49^{\circ}}$.

Anteriormente aos processos de privatização ocorridos, a grande maior parte dos serviços públicos era prestada por meio de empresas estatais. Tais empresas aluavam sempre em regime de monopólio de atividades, o que acabava por acarretar a acumulação de competências por tais entidades, visto que, além de prestar os serviços públicos, referidas companhias ainda exerciam grande parte das funções reguladoras relacionadas aos serviços prestados, posto que eram essas empresas que definiam as metas de universalização, as metas de qualidade dos serviços, os valores tarifários, etc,, uma vez que inexistiam órgãos públicos competentes para exercer a função regulatória. Como exemplo desta situação, podemos mencionar as empresas

48 A competência do Banco Central Brasileiro é bastante semelhante às competências do Banco Central Alemão (Die Deutsche Bundesbank), que, igualmente, controla as atividades das instituições financeiras públicas e privadas, nos termos do artigo $3^{\circ}$ da Lei Bancária Alemã (Bundesbankgesetz). Cf. KOHLS, Rainer. Bankrecht. $2^{a}$ edição - 1997. Ed. C. H. Beck. Munique. Página 22.

49 Por exemplo. Agência Reguladora de Serviços de Transportes Estadual de São Paulo ARTESP (SP), Comissão de Serviços Públicos de Energia - CSPE (SP), Agência Estadual de Regulação dos Serviços Públicos Delegados do Estado de Pernambuco - ARPE (PE), entre diversas outras. 
do sistema Telebrás, que acabavam por acumular as funções de prestadoras e reguladoras de serviços públicos.

Com efeito, a partir da realização dos processos de privatização e modernização dos serviços públicos no Brasil, adveio a segregação das atividades de regulação e prestação dos serviços públicos, ocorrida mediante a criação de órgãos reguladores, que passaram a ser competentes para definir as metas de universalização, as metas de qualidade, os valores tarifários, etc. Nesta toada, as empresas estatais que não foram incluídas nos processos de privatização passaram a estar, indubitavelmente. sujeitas à regulação setorial exercidas pelos órgãos reguladores, uma vez que não seria possível admitir-se que apenas as empresas privadas (concessionárias e permissionárias) de serviços público estivessem sujeitas a tal regulação, sob pena de violação do Princípio da Igualdade.

Sendo assim, é possível afirmarmos que as empresas estatais prestadoras de serviços públicos (independentemente de serem ou não concessionárias de serviços públicos), bem como aquelas exploradoras de atividades econômicas em sentido estrito, encontram-se sujeitas à regulação setorial exercida pelas agências reguladoras em seus respectivos setores, independentemente de exercerem em tais setores atividades econômicas em sentido estrito ou serviços públicos.

Apenas para exemplificar esta situação, podemos mencionar as empresas do Grupo Eletrobrás, que, para o desempenho de suas funções, estão estritamente sujeitas à regulação e à fiscalização exercidas pela Agência Nacional de Energia Elétrica - ANEEL, nos termos do inciso IV do artigo $3^{\circ}$ da Lei 9.427 , de 26 de dezembro de 1996, sem que haja qualquer restrição em razão de serem referidas empresas controladas pela União Federal.

Demais disso, por força do artigo $8^{\circ}$ da Lei 6.385, de 7 de dezembro de 1976 , qualquer empresa, privada ou pública (independentemente de ser exploradora de atividades econômicas ou prestadora de serviços públicos), que tenha capital aberto e que efetue a emissão de quaisquer valores mobiliários estará sujeita à fiscalização e à regulação exercida pela Comissão de Valores Mobiliários no mercado de capitais brasileiro, o que comprova, ainda mais, a sujeição das empresas estatais à regulação setorial.

Posto isso, passaremos a analisar a sujeição das empresas estatais às regras de regulação da concorrência. Esta nos parece ser a mais simples das questões analisadas neste item, uma vez que o artigo 15 da Lei 8.884/94 determina expressamente que referida lei aplica-se a todas as pessoas físicas ou jurídicas, de direito público ou de direito privado, ainda que exploradoras de monopólios legais ${ }^{50}$. Assim, parece-nos fora de qualquer questão a sujeição de todas as empresas estatais (exclusive, naturalmente, aquelas que exercem funções públicas) às regras de regulação da concorrência e à fiscalização realizada pelo CADE.

50 Dispõe o artigo 15 da Lei 8.884/94 (in verbis): "Art. 15. Esta Lei aplica-se às pessoas físicas ou jurídicas de direito público ou privado, bem como a quaisquer associações de entidades ou pessoas, constituidas de fato ou de direito, ainda que temporariamente, com ou sem personalidade jurídica, mesmo que exerçam atividade sob regime de monopólio legal." 
No exame desta questão, Pedro Dutra afirma com muita propriedade que " $a$ exploração de atividade econômica - a produção e a comercialização de bens e a prestação de serviços - por empresa sob controle estatal, dá-se em um mercado normalizado, regulado e fiscalizado, na forma da Lei, pelo Estado, incidindo as regras que desdobram esta função estatal também sob a empresa privada produtora de bens e prestadora de serviços, tais as regras de defesa da concorrência, de defesa do consumidor e de regulação especial de determinados mercados. Afastou o legislador, assim, a possibilidade de, tanto a empresa sob controle estatal quanto a empresa sob controle privado, na exploração de atividade econômica - na atuação em mercados de bens e serviços, quaisquer que sejam eles - porem-se a salvo da disciplina legal dos mercados econômicos; em uma palavra, atuarem à margem da intervenção estatal reguladora e fiscalizadora da atividade econômica" ${ }^{51}$

A luz do exposto neste item, entendemos que as empresas estatais, independentemente da atividade que realizam (serviços públicos, atividades econômicas ou ambos), estarão sujeitas à regulação estatal, tanto naquilo que concerne à regulação específica de determinado setor, quanto naquilo que concerne à regulação concorrencial e à repressão de infrações à Ordem Econômica, sujeitando-se, portanto, exatamente às mesmas regras a que se sujeitam as empresas privadas atuantes nos mesmos setores, sem qualquer forma de restrição.

\section{Conclusão}

Procuramos, ao longo deste trabalho, apresentar novas idéias e novos conceitos relacionados às empresas estatais, tanto naquilo que se refere a uma maior influência do direito privado em seu regime jurídico, verificada tanto no caso das empresas estatais exploradoras de atividades econômicas em sentido estrito, quanto das empresas estatais prestadoras de serviços públicos (neste último caso, por conta da existência de atividades privadas em seus segmentos de atuação), bem como naquilo que se refere a uma dominância do regime de direito público em seu regime jurídico (empresas estatais que exercem funções públicas).

Ademais, procuramos analisar e abrandar alguns dogmas existentes, notadamente relativos ao exercício de funções públicas pelas empresas estatais, que entendemos ser perfeitamente possível e admissível.

Desta forma, face o exposto ao longo deste trabalho, entendemos restar comprovada uma profunda alteração das funções das empresas estatais, bem como do regime jurídico a elas aplicável, o que nada mais é do que óbvia consequiência da alteração das funções de referidas entidades no novo contexto de atuação estatal.

\section{Bibliografia}

ARAGÃo, Alexandre Santos de. Agências Reguladoras e a Evolução do Direito Administrativo Econômico. $1^{\text {a }}$ Edição - 2002. Ed. Forense. Rio de Janeiro.

51 DUTRA, Pedro. Livre Concorrência e Regulação de Mercados. $1^{\mathbf{a}}$ edição - 2003. Ed. Renovar. Rio de Janeiro. Páginas 233 e 234. 
DELPINO, L. / GIUDICE, F. del / CARINGELLA, F. Compendio de Diritto Ammmistrativo. $13^{a}$ Edição - 2003. Ed. Edizione Simone. Nápoles.

DI PIETRO, Maria Sylvia Zanella. Direito Administrativo. $14^{\mathrm{a}}$ Edição - 2002. Ed. Atlas. São Paulo.

Empresas Estatais. Submissão à Lei $N^{\circ}$ 8.666/93. Aspectos Jurídicos-Constitucionais. In DI PIETRO, Maria Sylvia Zanella. Temas Polêmicos Sobre Licitações e Contratos. $5^{\text {a }}$ Edição - 2002. Ed. Malheiros. São Paulo.

Parcerias na Administração Pública. $4^{\mathrm{a}}$ Edição - 2002. Ed. Atlas. São Paulo, São Paulo.

DUTRA, Pedro. Livre Concorrência e Regulação de Mercados. $1^{a}$ Edição - 2003. Ed. Renovar. Rio de Janeiro.

GORDILLO, Augustín. Tratado de Derecho Administrativo. $5^{\text {a }}$ Edição - 2003. Ed. Del Rey. Belo Horizonte.

GRAU, Eros Roberto. A Ordem Econômica na Constituição de 1988. $7^{\mathbf{a}}$ Edição 2002. Ed. Malheiros. São Paulo.

GROTTI, Dinorá Adelaide Musetti. O Serviço Público e a Constituição Brasileira de 1988. $1^{2}$ Edição - 2003. Ed. Malheiros. São Paulo.

JUSTEN FILHO, Marçal. Comentários à Lei de Licitações e Contratos Administrativos. $8^{a}$ Edição - 2001. Ed. Dialética. São Paulo.

. O Direito das Agências Reguladoras Independentes. $1^{\text {a }}$ Edição -2002. Ed. Dialética. São Paulo.

Teoria Geral da Concessão de Serviços Públicos. $1^{\text {a }}$ Edição - 2003. Ed. Dialética. São Paulo.

KOHLS, Rainer. Bankrecht. $2^{a}$ Edição - 1997. Ed. C. H. Beck. Munique.

MAURER, Harmut. Algemeines Verwaltungsrecht. 14 ${ }^{\text {a }}$ Edição - 2002. Ed. C. H. Beck. Munique.

MELlO, Celso Antônio Bandeira de. Curso de Direito Administrativo. $13^{\mathrm{a}}$ edição - 2001. Ed. Malheiros. São Paulo.

Discricionariedade e Controle Jurisdicional. $2^{\text {a }}$ Edição $-5^{\text {a }}$ Tiragem 2001. Ed. Malheiros. São Paulo.

. Natureza e Regime Jurídico das Autarquias. $1^{2}$ Edição - 1968. Ed. Revista dos Tribunais. São Paulo.

SILVA, José Afonso da. Curso de Direito Constitucional Positivo. 22 $2^{\mathrm{a}}$ Edição 2003. Ed. Malheiros. São Paulo.

SUNDFELD, Carlos Ari. Direito Administrativo Ordenador. $1^{\text {a }}$ Edição, $3^{\text {a }}$ Tiragem - 2003. Ed. Malheiros. São Paulo.

. Empresa Pública Pode Exercer o Poder de Polícia. In Boletim de Direito Administrativo de Fevereiro de 1993. Páginas 98 e seguintes.

STREINZ, Rudolf. Europarecht. $6^{a}$ Edição - 2003. Ed. C. F. Muller. Heidelberg. TÁCITO, Caio. Direito Administrativo. $1^{\mathbf{a}}$ Edição - 1975. Ed. Saraiva. São Paulo. VOLLMÖLLER, Thomas. Die Wirtschaftliche Betätigung der öffentlichen Hand. In SCHMIDT, Reiner / VOLLMÖLLER, Thomas (Org.). Kompendium Öffentliches Wirtschaftrecht. $2^{\mathrm{a}}$ Edição - 2004. Ed. Springer. Heidelberg.

Gewerbrecht. In SCHMIDT, Reiner / VOLLMÖLLER, Thomas (Org.). Kompendium Öffentliches Wirtschaftrecht. $2^{a}$ Edição - 2004. Ed. Springer. Heidelberg. 